\title{
THE ESTROGEN CYTOSOL RECEPTOR OF FEMALE OVINE PITUITARY ${ }^{\mathrm{a}}$
}

\author{
Phyllis M. WISE ${ }^{b, c}$ and Anita H. PAYNE ${ }^{d}$ \\ Steroid Research Unit, Reproductive Endocrinology Program, Departments of Obstetics and \\ Gynecology and Biological Chemistry, University of Michigan, Ann Arbor, \\ Michigan 48104, U.S.A.
}

The biochemical parameters of estrone and estradiol binding to the cytosol fraction of ovine anterior pituitary were investigated. When incrcasing amounts of $\left[{ }^{3} \mathrm{H}\right]$ estrone or $\left[{ }^{3} \mathrm{H}\right]$ estradiol were incubated with the $105,000 \mathrm{~g}$ fraction from the pituitary, both hormones bound to a receptor with the same apparent $K_{\mathrm{D}}$ (mean \pm S.E., estrone $=1.40 \pm 0.30 \times 10^{-10}$ $M$, estradiol $=1.03 \pm 0.11 \times 10^{-10} \mathrm{M}$ ) and the same concentration of binding sites (estrone $=$ $3.22 \pm 0.58 \times 10^{-14}$ moles $/ \mathrm{mg}$ protein, estradiol $\left.=3.92 \pm 0.19 \times 10^{-14}\right)$. No conversion of $\left[{ }^{3} \mathrm{H}\right]$ estrone to $\left[{ }^{3} \mathrm{H}\right]$ estradiol under the experimental conditions used could be demonstrated. The receptor-estrogen complex exhibited identical sedimentation coefficients (7-8 S) with either hormone. The receptor was specific only for estrogens; neither 500-fold excess of testosterone nor progesterone affected binding. Competitive inhibition using increasing amounts of non-radioactive estrone or estradiol with $\left[{ }^{3} \mathrm{H}\right]$ estrone or $\left[{ }^{3} \mathrm{H}\right]$ estradiol resulted in parallel displacement of the radioactive hormone. These results strongly suggest that both hormones bind to the same pituitary cytosol receptor.

Keywords: estrone; 17ß-estradiol; anterior pituitary; cytoplasmic receptor.

Recently, the possibility that estrone is not only a precursor or metabolite of estradiol but also a biologically active estrogen in its own right has been explored. In the rat uterus, estrone binds to cytoplasmic and nuclear receptors (Rochefort et al., 1972; Ruh et al., 1973). Ruh et al. (1973) observed that estrone can stimulate uterine-induced protein (IP) synthesis; however, they were unable to demonstrate estrone bound to a macromolecule in a sucrose

${ }^{a}$ This investigation was supported in part by funds from Grant HD-04064 from NICHHD. bPostdoctoral fellow, Ford Foundation.

cPresent address: Department of Physiology, The University of New Mexico, School of Medicine, Albuquerque, New Mexico 87131.

${ }^{\text {d}}$ Requests for reprints should be sent to A. H. Payne. 
gradient. Relatively little work has been done in the pituitary: when incubating sheep pituitaries in the presence of estrone sulfate, both estrone and estradiol were found bound to macromolecules in the nucleus (Payne et al., 1973).

Evidence for a high affinity receptor for estrone in sheep is of particular interest since it appears that estrone may be an important biological estrogen. It is found in large quantities in uterine blood and peripheral blood of pregnant sheep (Skrzeczkowski et al., 1967; Challis et al., 1973a). There is significant interconversion between estrone and estradiol in several organs of the nonpregnant sheep (Kazama and Longcope, 1972, 1974). Because of the possible importance of estrone in the regulation of gonadotropin secretion by the anterior pituitary of sheep, the present experiments were undertaken to study the biochemical parameters that characterize estrone binding by cytoplasm of the sheep anterior pituitary, and to compare these parameters with those of estradiol in the same tissue.

\section{MATERIALS AND METHODS}

\section{Animals}

Sodium pentobarbital anesthesia was administered intravenously $(15 \mathrm{mg} / \mathrm{kg})$ to sexually mature female sheep in the non-breeding state prior to ovariectomy. Thirteen to 15 days post-castration the sheep were killed by decapitation following administration of pentobarbital and the anterior pituitary was removed. The tissue was placed in ice-cold $10 \mathrm{mM}$ sodium phosphate buffer, $\mathrm{pH} 7.4$, containing $1 \mathrm{mM}$ dithiothreitol, $10 \%$ glycerol, and $0.02 \%$ sodium azide (buffer $\mathrm{A}$ ).

\section{Preparation of cytosol}

All procedures for isolation of cytosol and for determination of estrogens bound to cytoplasmic receptors were carried out at $4{ }^{\circ} \mathrm{C}$. Tissue was freed from all adhering membrane, blotted dry, weighed, and then homogenized using 5 volumes of buffer A utilizing a polytron PT-10 tissue disintegrator (Brinkman). The homogenate was centrifuged for $1 \mathrm{~h}$ at $105,000 \mathrm{~g}$ in a Beckman Model L65B ultracentrifuge. The resulting supernatant was used for estrogencytosol binding studies. Protein concentrations of cytosol were determined according to the method of Warburg and Christian (1942).

\section{Incubation of cytosol and charcoal-binding assay}

Aliquots of cytosol, equivalent to $0.27-0.40 \mathrm{mg}$ protein, were incubated at $4{ }^{\circ} \mathrm{C}$ with $\left[{ }^{3} \mathrm{H}\right]$ estrone or $\left[{ }^{3} \mathrm{H}\right]$ estradiol in a total volume of $0.5 \mathrm{ml}$. Incubations 
were carried out for 20-24 h (unless otherwise indicated) since maximum binding of both hormones was found to occur by $18 \mathrm{~h}$ and remained unchanged for at least $48 \mathrm{~h}$. For determination of non-specific binding 100 times the concentration of the appropriate non-radioactive estrogen was added. At the end of incubation $1.0 \mathrm{ml}$ of charcoal suspension $(0.125 \%$ Norit A and $0.0125 \%$ Dextran 80 in buffer A) was added to adsorb unbound estrogen. The tubes were left for $15 \mathrm{~min}$ and centrifuged at $800 \mathrm{~g}$ for $10 \mathrm{~min}$. The supernatant was decanted directly into scintillation vials for determination of radioactivity. Counting efficiency was approximately $45 \%$.

\section{Metabolism of $\left[{ }^{3} \mathrm{H}\right]$ estrone}

Aliquots of cytosol, equivalent to $1.8 \mathrm{mg}$ protein, were incubated with $4 \times 10^{-11} \mathrm{M}\left(1.43 \times 10^{4} \mathrm{dpm}\right)$ or $1 \times 10^{-9} \mathrm{M}\left(3.58 \times 10^{5} \mathrm{dpm}\right)$ of $\left[{ }^{3} \mathrm{H}\right]-$ estrone in a total volume of $3 \mathrm{ml}$ in buffer A. Incubations were carried out at $4{ }^{\circ} \mathrm{C}$ for $20 \mathrm{~h}$. Incubations were terminated by the addition of ethanol to a final concentration of $75 \%$. The ethanol extract was evaporated to dryness and subjected to a dichloromethane-water partition. The dichloromethane extract was submitted to paper chromatography employing the following system: isooctane: toluenc: methanol: $\mathrm{H}_{2} \mathrm{O}, 25: 75: 80: 20$.

\section{Sucrose density centrifugation}

Aliquots $(0.2 \mathrm{ml})$ of cytosol $(0.8-1.6 \mathrm{mg}$ protein) which had previously been incubated with $\left[{ }^{3} \mathrm{H}\right]$ estrone or $\left[{ }^{3} \mathrm{H}\right]$ estradiol were layered onto a $4.8 \mathrm{ml}$ linear gradient of $5-20 \%$ sucrose in buffer A containing $10 \mathrm{mM} \mathrm{KCl}$. Some cytosol samples were frozen in a dry ice-acetone bath and stored at $-70{ }^{\circ} \mathrm{C}$ prior to sucrose density centrifugation. The gradients were centrifuged in a SW 50.1 Rotor (Spinco L2-65B) for $15 \mathrm{~h}$ at 230,000 $\mathrm{g}$. Fractions (approximately $0.25 \mathrm{ml}$ ) were collected and treated with dextran-charcoal to remove any unbound estrogen. Sedimentation coefficients of the cytosol receptors were estimated by comparison with those of glyceraldehyde-3-phosphate dehydrogenase (7 S) and alcohol dehydrogenase $(4.5 \mathrm{~S})$ run simultaneously with the cytosol.

\section{Materials}

$\left[6,7-{ }^{3} \mathrm{H}\right]$ Estrone $(40 \mathrm{Ci} / \mathrm{mmole})$ and $\left[6,7-{ }^{3} \mathrm{H}\right]$ estradiol $(48 \mathrm{Ci} / \mathrm{mmole})$ were obtained from New England Nuclear. Prior to incubation an aliquot of each was mixed with the appropriate crystalline steroid and recrystallized. The material was used only if the specific activity of the initial crystal was within $5 \%$ of the starting material. Non-radioactive estrone, $17 \beta$-estradiol, $17 \alpha$. estradiol, estriol, progesterone and testosterone were purchased from Steraloids and diethylstilbestrol (DES) from Schwartz-Mann. All were recrystallized prior 
to use. DNase, RNase, trypsin, chymotrypsin, alcohol dehydrogenase, and glyceraldehyde-3-phosphate dehydrogenase were obtained from Sigma.

\section{RESULTS}

Determination of dissociation constants $\left(K_{\mathrm{D}}\right)$ and concentration of cytoplasmic receptors

The effect of increasing concentrations of $\left[{ }^{3} \mathrm{H}\right]$ estrone or $\left[{ }^{3} \mathrm{H}\right]$ estradiol $\left(4 \times 10^{-11} \mathrm{M}\right.$ to $\left.1 \times 10^{-9} \mathrm{M}\right)$ on the amount of hormone specifically bound to cytoplasmic receptors was determined utilizing the anterior pituitary from each of five sheep. $K_{\mathrm{D}}$ and concentration of cytoplasmic receptors for each hormone was determined by Scatchard (1949) analysis. A representative plot from one sheep (no. 1) is illustrated in fig. 1. The apparent $K_{\mathrm{D}}$ and concentration of

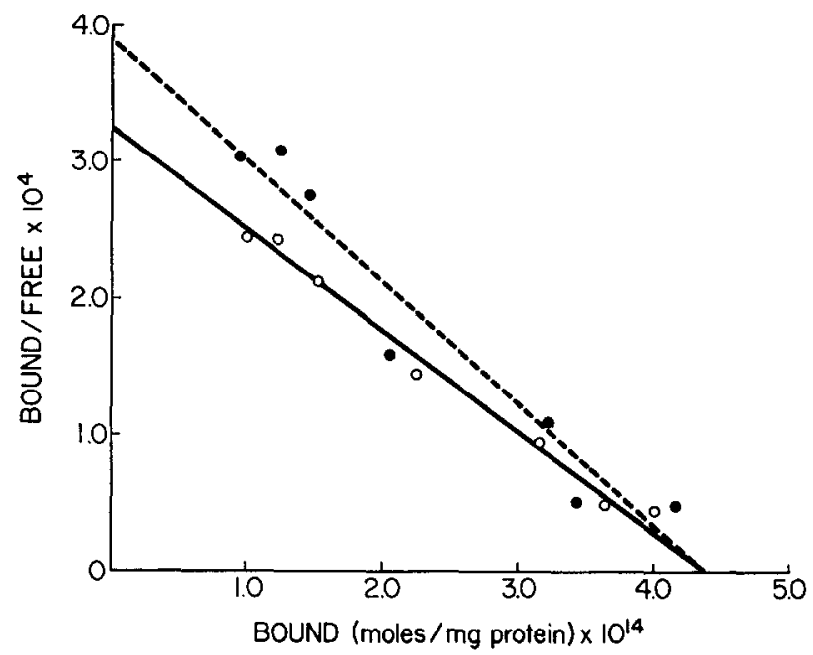

Fig. 1. The effects of increasing concentrations $\left(4 \times 10^{-11} \mathrm{M}\right.$ to $\left.1 \times 10^{-9} \mathrm{M}\right)$ of $\left[{ }^{3} \mathrm{H}\right]$ estrone and $\left[{ }^{3} \mathrm{H}\right]$ estradiol on the amount of estrogen bound by cytosol of the anterior pituitary from sheep no. 1 plotted according to Scatchard (1949); estrone, - - - - estradiol, - $\mathrm{O}-\mathrm{O}-$ Cytosol was incubated for $20 \mathrm{~h}$ at $4{ }^{\circ} \mathrm{C}$ with varying concentrations of $\left[{ }^{3} \mathrm{H}\right]$ estrone or $\left[{ }^{3} \mathrm{H}\right]-$ estradiol. Free estrogen was separated from bound by the dextran-charcoal binding assay. For determination of specifically bound $\left[{ }^{3} \mathrm{H}\right]$ estrogen, counts attributable to non-specific binding components, as determined by incubation of $\left[{ }^{3} \mathrm{H}\right]$ estrogen in the presence of 100 -fold excess of the appropriate non-radioactive steroid were subtracted from total bound counts. Free steroids (not bound by cytosol) were measured by subtracting bound radioactivity from total counts incubated. Bound steroid is expressed in moles $/ \mathrm{mg}$ protein and free steroid in moles per liter (M). Linear regression was determined by the least square method from the data obtained at each concentration of estrogen. 
Table 1

Anterior pituitary cytosol receptor interaction with estrone and estradiol. Cytosol was incubated for $20 \mathrm{~h}$ at $4{ }^{\circ} \mathrm{C}$ with varying concentrations of $\left[{ }^{3} \mathrm{H}\right]$ estrone or $\left[{ }^{3} \mathrm{H}\right]$ estradiol in the presence or absence of 100 -fold excess of non-radioactive hormone and specifically bound ${ }^{3} \mathrm{H}$ was determined by the charcoal-binding assay. $K_{D}$ and concentration of binding sites were determined graphically as described for fig. 1.

\begin{tabular}{|c|c|c|c|c|}
\hline \multirow[b]{2}{*}{ Sheep no. } & \multicolumn{2}{|c|}{ Estrone } & \multicolumn{2}{|c|}{ Estradiol } \\
\hline & $K_{\mathrm{D}}\left(\mathrm{M} \times 10^{10}\right)$ & $\begin{array}{l}\text { Binding sites (moles } \\
\text { estrone bound/mg } \\
\text { cytoplasmic protein) } \\
\quad \times 10^{14}\end{array}$ & $K_{\mathrm{D}}\left(\mathrm{M} \times 10^{10}\right)$ & $\begin{array}{l}\text { Binding sites (moles } \\
\text { estradiol bound } / \mathrm{mg} \\
\text { cytoplasmic protein) } \\
\qquad \times 10^{14}\end{array}$ \\
\hline 1 & 1.38 & 4.07 & 1.12 & 3.48 \\
\hline 2 & 2.56 & 3.41 & 0.77 & 3.96 \\
\hline 3 & 1.15 & 1.05 & 0.85 & 4.20 \\
\hline 4 & 0.81 & 3.20 & 1.06 & 3.52 \\
\hline 5 & 1.11 & 4.39 & 1.37 & 4.45 \\
\hline Mean \pm S.E. & $1.40 \pm 0.30$ & $3.22 \pm 0.58$ & $1.08 \pm 0.11$ & $3.92 \pm 0.19$ \\
\hline
\end{tabular}

binding sites for estrone and estradiol with the anterior pituitary cytosol of each sheep as well as the average $K_{\mathrm{D}}$ and the average concentration of binding sites are presented in table 1 . No significant difference $(P>0.05)$ was observed in either the $K_{\mathrm{D}}$ or the concentrations of binding sites utilizing either estrone or estradiol.

\section{Metabolism of estrone}

No $\left[{ }^{3} \mathrm{H}\right]$ estradiol could be detected when either $4 \times 10^{-11} \mathrm{M}$ or $1 \times 10^{-9} \mathrm{M}$ $\left[{ }^{3} \mathrm{H}\right]$ estrone was incubated with cytosol fractions of the anterior pituitary at $4{ }^{\circ} \mathrm{C}$ for $20 \mathrm{~h}$.

\section{Chemical nature of the receptor}

Io determine the chemical nature of the receptor, aliquots of cytosol from the pituitary were incubated with $\left[{ }^{3} \mathrm{H}\right]$ estradiol or $\left[{ }^{3} \mathrm{H}\right]$ estrone in the presence of DNase, RNase, chymotrypsin or trypsin at $27^{\circ} \mathrm{C}$ for $1 \mathrm{~h}$. To determine the effect of protein denaturation, an additional aliquot of cytoplasm was heated at $60{ }^{\circ} \mathrm{C}$ for $15 \mathrm{~min}$ followed by incubation with either hormone at $27^{\circ} \mathrm{C}$. As shown in table 2, binding was unaffected by DNase or RNase, but significantly reduced in the presence of trypsin, chymotrypsin, or by heat denaturation.

\section{Hormone specificity}

To determine the specificity of the receptor for estrone and estradiol, aliquots 
Table 2

Effect of enzymes and heating on binding of estrone or estradiol by cytosol of the anterior pituitary. Cytosol was incubated for $1 \mathrm{~h}$ at $27^{\circ} \mathrm{C}$ with $4 \times 10^{-11} \mathrm{M}\left[{ }^{3} \mathrm{H}\right]$ estrone or $4 \times 10^{-11} \mathrm{M}$ $\left[{ }^{3} \mathrm{H}\right.$ ]estradiol in the presence of $250 \mu \mathrm{g} / \mathrm{ml}$ deoxyribonuclease (DNase), or $250 \mu \mathrm{g} / \mathrm{ml} \mathrm{ribo-}$ nuclease (RNase), or $50 \mu \mathrm{g} / \mathrm{ml}$ trypsin, or $50 \mu \mathrm{g} / \mathrm{ml}$ chymotrypsin. An additional aliquot of cytosol was heated to $60^{\circ} \mathrm{C}$ for $15 \mathrm{~min}$ and then incubated in the presence of hormone (heat).

\begin{tabular}{llc}
\hline Estrogen & Treatment & Percent of control \\
\hline Estrone & DNase & 92.2 \\
& RNase & 88.2 \\
& Trypsin & 25.5 \\
& Chymotrypsin & 21.6 \\
& Heat & 35.3 \\
Estradiol & DNase & \\
& RNase & 88.7 \\
& Trypsin & 94.3 \\
& Chymotrypsin & 37.7 \\
& Heat & 27.7 \\
\hline
\end{tabular}

Table 3

Specificity of cytosol estrogen receptor of anterior pituitary. Cytosol was incubated with $1 \times 10^{-9} \mathrm{M}$ of $\left[{ }^{3} \mathrm{H}\right]$ estrone or $\left[{ }^{3} \mathrm{H}\right]$ estradiol plus $5 \times 10^{-7} \mathrm{M}$ non-radioactive steroids and percent inhibition of bound radioactive estrogen was determined. Hormones were dissolved in dimethylsulfoxide prior to addition of buffer. The control tube contained no unlabeled steroid. DES = diethylstilbestrol. Each value for the pituitary cytosol represents the mean of duplicate determinations from 3 sheep \pm S.E.

\begin{tabular}{llr}
\hline Estrogen $\left(1 \times 10^{-9} \mathrm{M}\right)$ & Unlabeled steroid added $\left(5 \times 10^{-7} \mathrm{M}\right)$ & Percent inhibition \\
\hline Estrone & Estrone & $78.2 \pm 0.4$ \\
& $17 \beta$-Estradiol & $91.8 \pm 4.0$ \\
& $17 u$-Estradiol & $75.9 \pm 0.4$ \\
& Estriol & $56.7 \pm 0.6$ \\
& DES & $95.2 \pm 0.2$ \\
& Progesterone & $6.6 \pm 2.2$ \\
& Testosterone & $8.7 \pm 2.1$ \\
Estradiol & & \\
& Estrone & $63.7 \pm 1.4$ \\
& $17 \beta$-Estradiol & $84.1 \pm 0.2$ \\
& $17 \alpha$-Estradiol & $64.3 \pm 2.7$ \\
& Estriol & $38.6 \pm 2.0$ \\
& DES & $93.5 \pm 0.5$ \\
& Progesterone & $0.6 \pm 0.6$ \\
& Testosterone & Not detectable \\
\hline
\end{tabular}


of cytosol were incubated with $1 \times 10^{-9} \mathrm{M}\left[{ }^{3} \mathrm{H}\right]$ estrone or $\left[{ }^{3} \mathrm{H}\right]$ estradiol plus non-radioactive competitors at a concentration of 500 times that of the radioactive hormonc. Binding of $\left[{ }^{3} \mathrm{H}\right]$ estrone or $\left[{ }^{3} \mathrm{H}\right]$ estradiol without addition of competitor was used as controls. The results are illustrated in table 3. The data indicate that the cytosol receptor of the pituitary is specific for estrogens with estriol exhibiting the least percent inhibition of those estrogens tested. The nonestrogenic steroid hormones, progesterone and testosterone did not compete with the binding of either $\left[{ }^{3} \mathrm{H}\right]$ estrone or $\left[{ }^{3} \mathrm{H}\right]$ estradiol.

\section{Competitive binding of estrogen and estradiol}

To determine whether estradiol and estrone bind to the same cytoplasmic receptor, $1 \times 10^{-9} \mathrm{M}\left[{ }^{3} \mathrm{H}\right]$ estradiol was incubated with cytosol and increasing amounts of non-radioactive estradiol or estrone in buffer $\mathrm{A}$. The estrogen was first dissolved in dimethylsulfoxide. The same type of experiment was carried out utilizing $\left[{ }^{3} \mathrm{H}\right]$ estrone. Logit percent of $\left[{ }^{3} \mathrm{H}\right]$ estradiol bound was plotted against the log of amount of competitor added. Fig. 2 illustrated that parallel

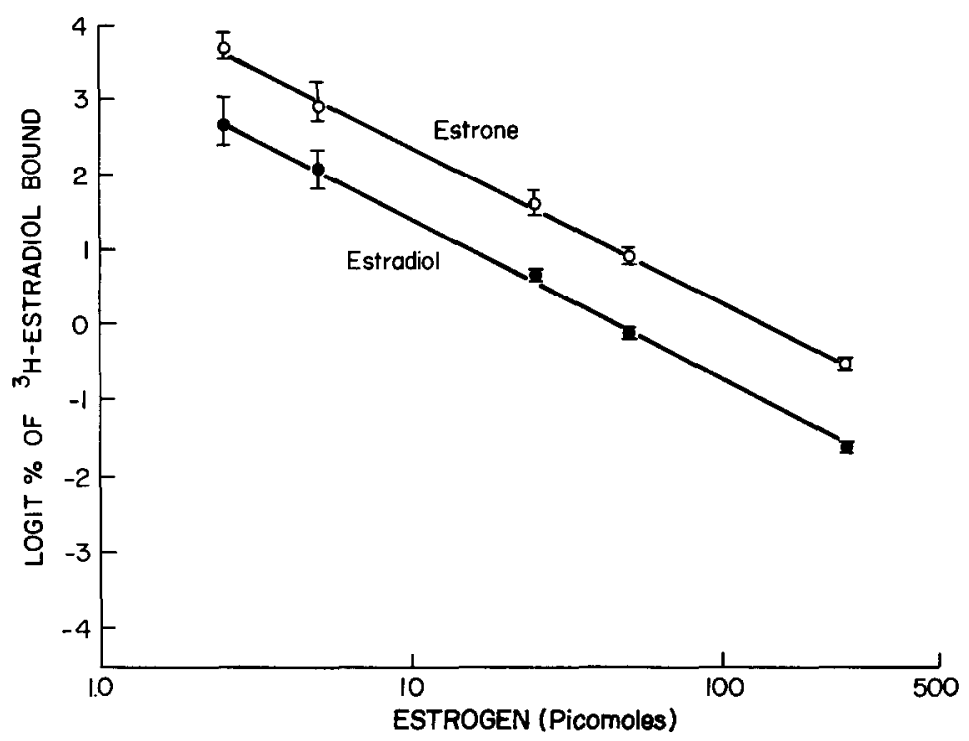

Fig. 2. Competitive binding of estrone and estradiol by cytosol of the anterior pituitary. $\left[{ }^{3} \mathrm{H}\right]$ Estradiol, $1 \times 10^{-9} \mathrm{M}$, was incubated alone or in the presence of increasing amounts of estrone or estradiol for $20 \mathrm{~h}$ at $4{ }^{\circ} \mathrm{C}$. Estrogens were dissolved in dimethysulfoxide prior to addition of buffer. Logit percent of $\left[{ }^{3} \mathrm{H}\right]$ estradiol bound was plotted against the log of amount of non-radioactive estrone or estradiol added. Each point represents the mean values of 3 determinations $\pm \mathbf{S}$.E. Linear regression was determined by the least square method from the mean values at each concentration of inhibitor. 

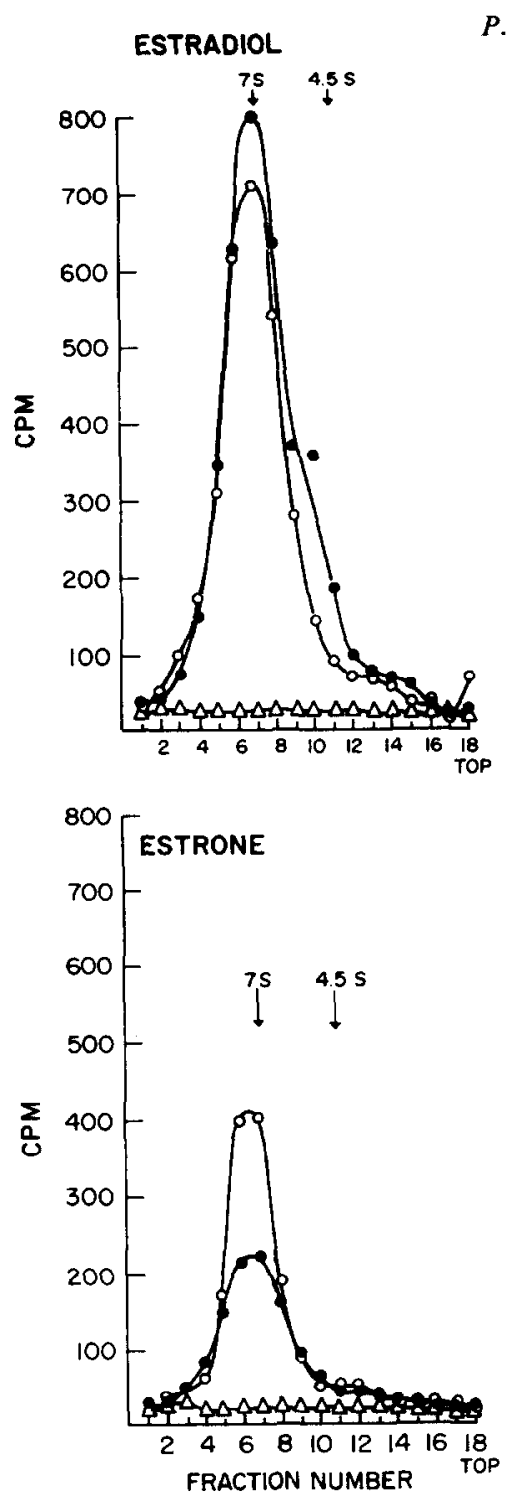

Fig. 3. Sucrose gradient ultracentrifugation of estrogens bound by anterior pituitary cytosol. Cytosol was incubated with $\left[{ }^{3} \mathrm{H}\right]$ estrone or $\left[{ }^{3} \mathrm{H}\right]$ estradiol, in the presence or absence of 100 -fold excess of the appropriate hormone, for $20 \mathrm{~h}$ at $4{ }^{\circ} \mathrm{C}$ either immediately after preparation of tissue or following thawing of cytosol which previously had been frozen and stored at $-70^{\circ} \mathrm{C}$. Aliquots $(0.2 \mathrm{ml})$ of labeled cytosol were layered on $5-20 \%$ sucrose gradients $(4.8 \mathrm{ml})$ containing $10 \mathrm{mM} \mathrm{KCl}$, and centrifuged for $15 \mathrm{~h}$ at $230,000 \mathrm{~g}$. Fractions $(0.25 \mathrm{ml})$ were collected and treated with dextran-charcoal prior to determination of radioactivity. Glyceraldehyde-3-phosphate dehydrogenase $(7 \mathrm{~S})$ and alcohol dehydrogenase $(4.5 \mathrm{~S})$ were used as sedimentation markers (indicated by arrows). Before freezing, ( freezing, $(\mathrm{O}-\mathrm{O})$; in the presence of 100 -fold excess of appropriate estrogen, $(\triangle \longrightarrow-\triangle)$. 
displacement was obtained when radioactive estradiol was incubated with increasing amounts of non-radioactive estradiol or estrone. Similar data were obtained with $\left[{ }^{3} \mathrm{H}\right]$ estrone as the radioactive ligand. This is consistent with estrone and estradiol binding to the same cytoplasmic receptor.

\section{Sucrose gradient ultracentrifugation}

Binding of $\left[{ }^{3} \mathrm{H}\right]$ estrone and $\left[{ }^{3} \mathrm{H}\right]$ estradiol was demonstrated by sucrose density centrifugation. Cytosol was incubated with hormone for $20 \mathrm{~h}$ at $4{ }^{\circ} \mathrm{C}$ prior to layering on a 5-20\% sucrose gradient. Data in fig. 3 demonstrate that both estrone and estradiol bind to a 7-8 S protein in the cytoplasm. The specificity of this binding is evident as no such peak of radioactivity was observed when 100 times the concentration of the appropriate non-radioactive hormone was added to the cytosol prior to incubation. Freezing of the cytosol did not affect the extent of binding of either hormone as the same peak was observed (fig. 3) when previously frozen and stored cytoplasm was utilized to study binding.

\section{DISCUSSION}

The present study demonstrates that the anterior pituitary of female sheep contains a high-affinity, low-capacity cytoplasmic receptor specific for estrogens. The data suggest that both estrone and estradiol bind to the same receptor as indicated by the fact that: (a) the apparent $K_{\mathrm{D}}$ 's and binding capacities for estrone and estradiol are not significantly different, (b) the same hormones compete with the binding of each of the estrogens, (c) parallel slopes result from competitive inhibition studies using increasing concentrations of estrone and estradiol with a given amount of either of the ${ }^{3} \mathrm{H}$-labeled hormones, and (d) the estrone-receptor complex and the estradiol-receptor complex exhibit the same sedimentation constant on centrifugation in a sucrose density gradient. The similarity of these biochemical parameters is not due to conversion of estrone to estradiol since no such conversion at the lowest or highest concentrations utilized in the present experiment could be demonstrated.

The mean value observed for the dissociation constant of estradiol in pituitary cytosol of sheep is in the same range as that reported for the rat (Korach and Muldoon, 1974; Notides, 1970). However, the sheep pituitary appears to have a lower binding capacity than that reported for the rat. The similarity in the $K_{\mathrm{D}}$ 's (table 1 ) observed for estrone and estradiol indicates that these two estrogens bind to the cytoplasmic receptor of the anterior pituitary with approximately the same affinity. 
Both receptor-bound estrone and receptor-bound estradiol of the anterior pituitary appear in the same fraction in a sucrose density gradient, suggesting that the protein receptor for both hormones is the same entity. The sedimentation constant of approximately $7 \mathrm{~S}$ observed in this study, agrees with previous reports with the same target organ of the rat (Notides, 1970).

The receptor has the characteristics of a protein and was found to be stable upon freezing in the presence of $10 \%$ glycerol. The latter differs from the finding of Korach and Muldoon (1974), who reported that the cytosol estradiolreceptor complex from rat anterior pituitary was labile to freezing. The difference could be due to the absence of glycerol in the buffer in the studies by Korach and Muldoon (1974).

Until recently very little attention has been paid to estrone since early studies reported little or no affinity of rat uteri for this hormone (Jensen and Jacobsen, 1962). Jensen and Jacobsen (1962) stated that any biological activity of estrone could be attributed to its ability to be converted to estradiol. However, no conversion of $\left[{ }^{3} \mathrm{H}\right]$ estrone to $\left[{ }^{3} \mathrm{H}\right]$ estradiol was found under the experimental conditions of this study. Recently Kazama and Longcope (1974) and Challis et al. (1973b) reported the uptake of estrone by ovine brain tissue during intravenous infusion of this estrogen. The demonstration in the present study of the similar affinities of estrone and estradiol for the cytoplasmic receptor of the anterior pituitary in female sheep suggests that both these estrogens may play an important role in the maintenance of serum gonadotropins at base line levels during anestrus (Roche, 1969; Roche et al., 1970).

\section{ACKNOWLEDGEMENTS}

The authors express their appreciation to Douglas Doop for his help in the care, maintenance, and surgery of the sheep, and to Dr. Robert P. Kelch for helpful discussion of the manuscript.

\section{REFERENCES}

Challis, J. R. G., Harrison, F. A. and Heap, R. B. (1973a) J. Endocrinol. 57, 97.

Challis, J. R. G., Harrison, F. A. and Heap, R. B. (1973b) J. Endocrinol. 58, 435.

Jensen, E. V. and Jacobson, H. I. (1962) Recent Prog. Horm. Res. 18, 385.

Kazama, N. and Longcope, C. (1972) Endocrinology 91, 1450.

Kazama, N. and Longcope, C. (1974) Steroids 23, 469.

Korach, K. S. and Muldoon, T. G. (1974) Biochemistry 13, 1932.

Notides, A. C. (1970) Endocrinology 87, 987. 
Payne, A. H., Lawrence, C. C., Foster, D. L. and Jaffe, R. B. (1973) J. Biol. Chem. 248, 1598. Roche, J. F. (1969) Ph. D. Thesis, University of Illinois, Urbana.

Roche, J. F., Foster, D. L., Karsch, F. J., Cook, B. and Dziuk, P. J. (1970) Endocrinology $86,568$.

Rochefort, H., Lignon, F. and Capony, F. (1972) Biochem. Biophys. Res. Commun. 47, 662.

Ruh, T. S., Katzenellenbogen, B. S., Katzenellenbogen, J. A. and Gorski, J. (1973) Endocrinology 92, 125.

Scatchard, G. (1949) Ann. N. Y. Acad. Sci. 51, 660.

Skrzeczkowski, L., Dobrowolski, W. and Domanski, E. (1967) Endokrynol. Polska 18, 195.

Warburg, O. and Christian, W. (1942) Biochem. Z. 310, 384. 